\title{
- CONTAMINANT, COMMODITY AND \\ FUEL: A Multi-sited Study of Waste's roles in Urban Transformations from Italy to Austria
}

\author{
INGRID BEHRSIN AND SALVATORE PAOLO DE ROSA
}

\begin{abstract}
This article traces the flow of municipal solid waste from southern Italy through a waste-to-energy facility and district heating system in Austria, examining the roles that waste's transformation from contaminant to commodity to fuel plays in interconnected, distributed, and contested urbanization processes. It contends that, while metabolic circulation hides socioecological costs in one place to facilitate valorization in another, specific spatial configurations emerge through territorialization-of waste economies, in this case-providing the spatial base to realize metabolic flows and to anchor political narratives. A decisive effect is that certain patterns of urbanization become locked-in, impeding alternative metabolic transitions and spatial configurations. Attending to the coproduction of three sites-Naples, Italy; Zwentendorf, Austria; and St Pölten, Austria-through the circulation and transformation of waste and energy the article provides an empirical multi-sited case study of a political ecology of urbanization.
\end{abstract}

\section{Introduction}

Despite its massive size, on most days the blue-gray Zwentendorf waste-toenergy (WTE) facility all but blends in with the horizon. Its 500,000-tonne-per-year bunker capacity makes it one of the largest of such facilities in Europe and the largest in Austria. The facility is operated by Energie Versorgung Niederoesterreich (EVN), a publicly traded entity, majority owned by the state of Lower Austria (EVN, 2002). While the bulk of municipal solid waste (MSW) combusted in this incinerator is produced within the region, EVN began importing waste from beyond Austria's national borders in late 2013. From the plain of Campania in southern Italy, hundreds of rail cars packed with waste are delivered weekly, contributing approximately $20 \%$ of the facility's annual throughput (Kowalcze, 2015) and helping the city of Naples catch its breath from the recurring stalls in MSW collection and disposal there.

The Zwentendorf incinerator is a crucial node in a network of interlinked urbanization processes. A fraction of the incoming waste from abroad that powers the facility stems from Naples' recent history of broken and corrupted environmental governance. From that waste, the WTE facility generates energy that is distributed in the form of electricity and heat. While the energy network that radiates from the incinerator cuts through and powers up cities, cities are not this network's exclusive domain. The Zwentendorf incinerator is in fact located well beyond the jurisdictional boundary of some of the municipalities that purchase its power. Rather than being merely a peripheral rural backwater, Zwentendorf and the incinerator located there are crucial sites in a 'complex web of urbanization' (Harvey, 1996: 38): they play important roles in the production of interlinked urbanization processes unfolding concurrently in

\footnotetext{
The authors would like to thank the ENTITLE network for facilitating their collaboration. We are also grateful to four anonymous IJURR reviewers for their constructive feedback, which strengthened this work. Ingrid Behrsin received support for this research from the Austrian Agency for International Cooperation in Education and Research, the Austrian Marshall Plan Foundation, the EU Center of Excellence, the University of California Institute for Global Conflict and Cooperation, the UC Davis Center for Regional Change, the UC Davis Institute for Social Sciences, the UC Davis Geography Graduate Group, the UC Davis College of Agriculture and Environmental Sciences, and the UC Davis Office of Graduate Studies. Salvatore Paolo De Rosa has received support for work on this article by FORMAS (Swedish Research Council for Sustainable Development) under the National Research Programme on Climate (Contract: 2017-01962_3). Any errors or inconsistencies remain our own.
} 
both the municipality surrounding the incinerator, and the dispersed regional capitals Naples, Italy, and St Pölten, Austria.

In this article, we argue that while metabolic circulation hides socioecological costs in one place to facilitate valorization in another, specific spatial configurations emerge through territorialization-of waste economies, in this case-to obscure opportunities for alternative, more sustainable, metabolisms. Waste that is a nuisance and brings chaos in Naples becomes the source of 'clean' power and contributes to an imaginary of political stability in Austria. Thanks to physical structures and farreaching movements, MSW's inherent heterogeneity and mutability thus combines with place-specific histories, policies, accumulation strategies and dedicated protocols to produce different expressions of an interlinked urbanization process. Whereas in Naples waste mishandling within a state of emergency served private profitmaking and rent-seeking activities with unequally distributed socioecological costs, contested locally by mass protests, within the state of Lower Austria, the same waste became both an important source of municipal revenue and a symbol of industrial and green energy prowess. In exploring the dynamic relationship between circulation and territorialization that plays out in this multi-sited case, the article contributes to two central debates of our times, namely, the interplay between local socio-ecologies and networks of production and destruction stretching globally, on the one hand, and the social, spatial and political limits preventing the emergence of alternative socioecological relations, on the other.

The article proceeds in the next section by reviewing relevant literature in urban political ecology (UPE) that aims to better explain urbanization as expansive and multi-sited, yet simultaneously grounded in physical space. In the third section, we suggest that these efforts can be strengthened by a deeper engagement with literature on territorialization. In particular, by turning to a strand of political geography that has focused on the link between power relations and the making of spatial units, or territories, we establish a productive dialogue between dynamics of territorialization and UPE's treatment of capitalist urbanization and socioecological relations. The fourth section turns to the multi-sited case study. In this section, we trace the circulation of heterogeneous shipments of solid waste and its ontological and material transformations from southern Italy, through energy harvesting processes in Zwentendorf, Austria, to district heating systems in the Austrian regional capital, St Pölten. Throughout each section, we demonstrate that this waste stream's interconnected movements and transformations prompt the production of specific spaces, catalyze simultaneous territorialized urban imaginaries in each location which in turn serve to foster capital accumulation processes, and obfuscate political struggles and socioecological costs of waste persistence. The conclusion summarizes the article's main claims, and suggests how future studies might contribute additional analyses of waste's role in the political ecology of urbanization.

This article is informed by fieldwork conducted in Austria by the first author and in Italy by the second author between 2013 and 2015. For sites in Austria, it draws on document and periodical analysis, and 85 semi-structured interviews with a range of actors involved in solid waste management, energy infrastructure development, and municipal governance processes. Interviews were held in locations determined by interviewees, and were conducted in German or English. When possible, interviews were recorded, with interviewees' permission, and transcribed in the original language. They were subsequently coded and analyzed using an open coding approach (Emerson et al., 2011). Data collection also occurred during four guided site visits to the Zwentendorf WTE facility, a WTE facility community advisory committee meeting in Zwentendorf, Austria, and a three-day WTE industry conference in Brussels, Belgium. These data provided insight on the practices-labor, knowledge and decisions-through which WTE facilities are managed, as well as the subjectivities the 
Zwentendorf WTE facility employees and nearby inhabitants develop in relation to the incinerator. In the Italian site, data collection focused on the northern part of Naples' province and the southern part of Caserta's province in the region of Campania. Waste metabolisms were investigated through document analysis of management projects, parliamentary commissions' dossiers, activists' reports, media accounts and scientific studies on pollution and residents' health. By critically combining these sources, and by triangulating data between sources and with interviews, the technical, regulative and criminal aspects of waste trade, transformation and disposal, their spatial and socioecological implications, and the narratives produced around these issues were clarified. Forty-two interviews, complemented by participant observation, included 30 with activists, four with local farmers, four with waste management experts, and four with public officials.

Expanding UPE's toolkit: territorialization and socioecological metabolisms

Like political ecology, the broader discipline from which it developed, urban political ecology focuses on theorizing and formulating radically democratic political approaches to the production of the environment (Heynen et al., 2006). It adopts a normative view, as well as an 'intensely critical' perspective that sets it apart from other urban scholarship traditions (Keil, 2003: 724). UPE has been described as a 'theoretical platform for interrogating the complex, interrelated socioecological processes that occur within cities' (Swyngedouw and Heynen, 2003: 906) and 'an integrated and relational approach that helps to untangle the interconnected economic, political, social, and ecological processes that together go to form highly uneven urban landscapes' (Heynen, 2014: 602). A UPE orientation helps demonstrate the role that cities play in pressing environmental issues (Heynen, 2014), as well as the ways in which marginalized social groups experience socio-environmental problems most acutely (Heynen et al., 2006). UPE analyses contribute nuanced understandings of how ecological systems are intertwined with urbanization processes, and are uniquely positioned to attend to the ordering of "good" and "bad" natures according to socially constructed understandings of what the city ought to be' (Castán Broto and Bulkeley, 2013: 1936). In doing so, a UPE approach helps explain why and how particular manifestations of material nature end up where they do, and to what socioecological effect.

One of the core heuristics that UPE scholarship has enrolled to analyze these processes is that of metabolism. Indeed, Swyngedouw's (1996) use of the term to describe the processes through which nature is urbanized has become a common conceptual tool in much UPE work. In contrast to bio-centric interpretations, Swyngedouw's interpretation connotes 'the dynamic internal relationships between humans and nature that produce socio-natural entanglements' (Heynen et al., 2006: 7), and includes circulations and transformations of capital, labor and materials. According to Heynen (2014: 599) UPE's reworking of Marx's original idea of metabolism to call out the 'interrelated and interconnected socionatural urban processes, and their resulting uneven configurations' has been one of the field's main contributions. Much UPE work from the past 15 years is shot through with analysis of urban socioecological dynamics that draws from this conceptualization (cf. Gandy, 2005; Kaika, 2005; Monstadt, 2009; Newell and Cousins, 2014). Recently, Arboleda (2016) has drawn on the concept to interrogate the interconnected socioecological processes surrounding a Chilean mining community, demonstrating how UPE's emphasis on metabolic processes can help demystify the visual and ideological exclusions of networks and spaces embedded in multi-sited urbanization processes, and the normalization of the fetishization and commodification of nature (Kaika, 2005).

A second central contribution from UPE scholarship is that urbanization can be viewed as 'a process of de-territorialisation and re-territorialisation through metabolic 
circulatory flows' (Heynen et al., 2006: 106). This means that the multiple flows at the heart of the process of urbanization both produce and rely on constructed physical spaces tailored to make such flows productive. Rice (2010), for example, has analyzed territorialization efforts evident in Seattle's carbon emissions regulatory schemes. Her study demonstrates that territorialization manifests in the organization and exercise of social and political power within a subnational space-Seattle, Washington. In our view, however, Swyngedouw's early proposition opens up a very productive, if currently relatively underdeveloped, cross fertilization of UPE with scholarship on territorialization from political geography. We suggest that this approach helps situate technopolitical territorialization strategies occurring within one jurisdiction to broader, relational, urbanization processes. Specifically, it unearths the processes implicated in the production of systems of resource control by state and non-state actors through a focus on the ways in which authority is secured, institutions are created, rights are endowed to-or deprived from-specific groups, and nature is transformed into resources and commodities in the process. By foregrounding territorialization processes, we aim to show that as metabolic circulation hides socioecological costs in one place to facilitate valorization in another, specific spatial configurations emerge through territorialization-of transnational waste economies, in this case-to obscure opportunities for alternative, more sustainable, metabolisms.

In recent years, within political geography there has been a renovated interest on territory and territorial politics towards original applications and directions of analysis (for reviews, see Painter, 2010; Bryan, 2012; Halvorsen, 2018; Rasmussen and Lund, 2018). These studies build on a conceptual tradition that sees territory, in the most basic sense, as a space that is 'made' throughout historical processes via a variety of social practices (Sack, 1986; Vandergeest and Peluso, 1995). Likewise, this literature extends a definition of territorialization as the social strategy of creating bounded geographical areas for particular outcomes by classifying, regulating, and enforcing certain uses of space, people and resources within (Rasmussen and Lund, 2018), thus seeing territories as strategic phenomena and political projects of control (Murphy, 2012). This perspective opens to the appreciation of how both state and non-state actors, by drawing and policing boundaries, can exercise their-de jure or de facto-authority over the objects and people within the bounded area and restrict access to outsiders, thus materializing a territory.

Spatial units established by the state for a given purpose can become the source of profits or rents for those who are entitled (or can exert the power) to claim authority over the economic gains from specific land uses and territorial relations (Christophers, 2014). Enclosure and privatization as mechanisms of territorialization establish barriers-physical or institutional-around certain resources, thus contributing to making and isolating the resource itself from messy biophysical realities, and securing access for those in control. Substantial control may have a legal rationale, be based on economic or cultural dominance, establish rule through terror, or a mix of the three. Violence can become a major component in the making of territories, even just as threat or as memory. Such practices for realizing control over space have been defined acts of territorialization (Roth, 2008; Corson, 2011). Yet, every act of territorialization is configured in relation to previous territorializations (Roth, 2008; Bluwstein and Lund, 2018) and to competing territorializations (De Rosa, 2018) that influence the elaboration and consolidation of new territories. Following Painter (2010), we maintain that any territory should be approached also as the effect of networked socio-technical practices enrolling both humans and non-humans into the production of spaces. Painter's suggestion, by framing territory as an effect that is generated by and depends on extralocal relations, rejects the opposition between territorial and network thinking, and echoes UPE's emphasis on the scalar connections of metabolic circulatory flows that materialize urban environments. 
Waste economies have emerged as important landscapes through which territorialization processes play out. Critical waste studies have opened up waste ontologically to explain how these processes work. Waste mobility scholars have effectively demonstrated how the different meanings and values that waste engenders articulate with technological opportunity to establish and propel circulation among regulatory and economic value regimes (Clapp, 2002; Brownell, 2011; Grant and Oteng-Ababio, 2012; Crang et al., 2013). Others have shown how waste can become a political catalyst for manifesting polities that offer counter claims to contest or rework particular territorializations (Moore, 2008; 2009; Armiero and D'Alisa, 2012). Waste infrastructure's multiple valences contribute ontological opportunities that serve political purposes (Harvey, 2017; Behrsin, 2019). MSW in particular is both indeterminate and heterogeneous (Hird, 2012). As Gille (2013: 5) argues, its indeterminacy 'can be used to point out the limits of waste management experts' haughty reassurances ... but it can also undermine ... victims of toxic landfills'. Indeed, in current capitalist societies, waste's polyvalence and heterogeneity is increasingly incorporated into process of commodification aimed at extracting economic value from it (O'Brien, 1999). Such commodification unfolds through regulative schemes entangled with human labor and socio-technical processes. Since waste is not 'made' as such, but it is a byproduct of extraction, production and consumption regimes, its commodification requires both a political-economic framework that regulates the conversion of value (O'Brien, 1999; 2007) and the design of concrete socioecological spaces to realize this value. This perspective focuses on the processes that regulate the conversion of value from waste, but also allows to 'demonstrate the physical and social consequences of a waste material metamorphosing into another as it traverses the circuits of production, distribution, consumption, reclamation and annihilation' (Gille, 2007). Our aim in this article is to bring these strands of critical waste scholarship together to contribute more nuanced understandings of how waste circulations and (counter-)territorialization processes intersect, with an emphasis on illuminating the coproduction of urban spaces and waste circulations through territorialization. This dialectic process locks certain types of waste circulations into place, or at the very least impedes alternative waste relations.

Territorial representations, and the contested processes through which they are produced, are always historically and geographically specific (Brenner and Elden, 2009; Crampton, 2010; Elden, 2010). To that end, the following section aims to ground the above discussion in a multi-sited case study of waste flows and transformation from southern Italy to central Austria. It provides an empirical and spatialized illustration of how territorialized spaces are both created by waste circulations, and also create possibilities for waste to function as both a contaminant, as well as a valuable resource (Reno, 2015). Specifically, it traces how the movement of MSW and its constitutive characteristics, such as repugnant odors and latent energy, participate in performing, and also are enrolled in, the territorialization of urban spaces. It describes how municipal elites enlist waste to create territorially bounded spatial realities and imaginaries of and within their jurisdictions to foster capital accumulation processes. This produces urban spaces that are linked by the fluid circulation of matter beyond jurisdictional confines.

\section{Findings}

Naples, Italy: waste occupation, capital accumulation and contested contamination

In 2008, shocking scenes of Naples' waste-strewn streets circulated among major international media outlets. These articles and their accompanying photos depicted families stepping gingerly around waist-high piles of smoldering refuse, conveying evocative images of an apocalyptic inferno (Kington, 2007; Rosenthal, 2008; Dines, 2013). In Naples, mountains of MSW accumulated for months in central areas. The 
growing heaps of rubbish were accompanied by a surge of public unrest, with mobilized residents calling for not only an end to the squalor, but also an overhaul of the antidemocratic governing arrangements that produced it (D'Alisa et al., 2010). Protesters were not necessarily unified in their motivations (Armiero and D'Alisa, 2012), but came together to call attention to their perceived position as the dumping ground for northern Italy's industries (Kaye, 2011), to corruption (Nadeau, 2010), to cancer concerns (Kington, 2007), and to contest the government techno-managerial plan by proposing alternative waste management schemes. Indeed, since the declaration of an emergency regime for MSW management in 1994-which conferred to a dedicated government agency extraordinary powers to shape the urban waste cycle and its spatial configuration through public-private partnerships-Campania was subjected to a project based on landfills, incinerators and storage areas that unfolded through the top-down imposition of management sites resulting from agreements between the government agency, a multinational corporation, subcontracting companies and landowners (De Rosa, 2018).

For municipal and national political leaders, the compounded crises of Naples' streets strewn with waste and region-wide civil unrest posed both an image and an economic crisis. As a Neapolitan tourism councilor stated, 'we have $112 \mathrm{~km}$ of country walks, a marine park and award-winning restaurants. Why do we have to transmit this filthy image to the media?' (Kington, 2007). Tourism, the largest contributor to the regional economy (Pomeroy, 2008), fell drastically. Furthermore, the agricultural sector had a decrease of between $25 \%$ and $75 \%$ in prices paid to producers (INEA, 2014), and Moody's downgraded Naples' debt in the context of the waste debacle (Moody's Investors Service, 2008). Conversely, local populations perceived the crisis as manufactured. As E, an activist told us: "we realized that behind the "waste emergency" there was again the attempt to induce a shock to make space for a specific entrepreneurial sector and for a specific economy' (interview, Naples, 7 March 2014). Their main concerns addressed the issues of health, local development, and long-term sustainability of the MSW management system. Initially, people were mobilized by the sensuous perceptions of detrimental socio-environmental changes-materialized by bad smell from landfills, toxic fires and illegal dumps. In the account of M, a local activist: 'I became interested in the environment because every night I smelled the stink, and when I walked the suburbs and the countryside I saw an unimaginable shit. I told myself this is why we get sick!' (interview, Caserta, 12 February 2014). In reaction to this state of affairs, local communities targeted by the government plan organized into grassroots movements and engaged in a work of collective self-formation over the causes and effects of waste flows and disposal (Armiero and De Rosa, 2018).

Activists contested the hegemonic discourse that framed incinerators, landfills and processing facilities as the only solution for 'modern' waste management, rejecting the authoritarian governance of waste that they perceived as a technocratic project primarily driven by private profiteering rather than concern for the environment and human safety. Instead, also thanks to exchanges and affiliations with national and international networks (like GAIA and Zero Waste Alliance) they campaigned for alternative waste management practices based on reduction, reuse, sorting and recycling of garbage. The consolidation of international partnerships culminated in the organization of the Fifth Zero Waste International Alliance Conference in Naples at the beginning of 2009. However, effective recycling schemes were only implemented from 2012 onwards in the municipalities between Naples and Caserta, finding immediate resonance with local populations. What prevented an earlier implementation was the interest by the corporation in charge of the project, backed by the special powers of the government agency, to process, store and eventually burn for profit as much MSW as possible.

Indeed, the corporation successfully lobbied for contractual benefits to boost its profits from waste incineration (Rabitti, 2008). It obtained, first, the right to store processed urban garbage, and second, the right to decide unilaterally the localization of 
facilities. Such privatization of urban and rural planning privileged the logistical needs of the corporation. The logic behind the company's desire to store bundles of MSW before the construction of the incinerator lies in Italy's generous renewable energy subsidies for electricity produced by burning garbage. To maximize profits, the corporation collected, processed and stored as much trash as possible. Such hunger for space led to the proliferation of rents capture by landowners, who could rely on a steady flow of rents paid for hosting trash once their piece of land was included in the network of territories of waste management. Between 2000 and 2009, 16 temporary storage sites arose for accommodating between 6 and 7 million tons of processed MSW, the so-called ecoballe (eco-blocks). Almost all of these facilities still stand in 2019. Armiero and D'Alisa (2012; 2013) have calculated that the packaged trash, if burned, could have generated around $€ 1$ billion from subsidies for the corporation. According to data from the latest Parliamentary Commission on Waste (2018), the costs sustained by the public for the lease of land where the waste blocks are currently amassed, as of 31 December 2017, amount to $€ 23,793,587$.

Upon his re-election in 2008, then Italian prime minister Silvio Berlusconi fulfilled his campaign promise to clear Naples' central streets of garbage within 10 days (Nadeau, 2010). Through a tactic that combined bypassing democratic institutions, launching initiatives to court foreign capital, and thanks to the 'temporary' waste storage sites, political and economic elites together endeavored to improve the 'national and international image of Naples' (D'Alisa et al., 2010: 245). That same year, through the law $123 / 2008$, the government declared all waste management facilities areas of 'national strategic interest' guarded by the army. This meant that the sites for urban waste management in Campania became territorialized as military areas. Behind barbed wire and soldiers impeding public scrutiny, the suspension of ordinary law systematically allowed for loose environmental safeguards and checks.

While the techno-managerial initiatives described above have largely succeeded in quieting the circulation of dramatic images featuring rubbish heaped in central Naples, the garbage has not disappeared. First, it is being pushed beyond the city's margins where the 'slow violence' of land toxification continues (Nixon, 2011): the waste is increasingly, and illegally, dumped in unsanctioned landfills (D'Alisa et al., 2010; Donadio, 2010; Armiero and D'Alisa, 2013), burned in the one existing, and questionably regulated, local incinerator in Acerra (Pasotti, 2010; Ridet, 2010), and accumulated in militarized storage sites. Such an accumulation of waste produces hybrid socioecological configurations throughout Campania in which contaminants defy formal and informal 'borders' and circulate within environmental matrices and through human and nonhuman bodies in unpredictable ways, with consequences that are still disputed (D'Alisa et al., 2017). In 2005, the Regional Plan for Remediation of Polluted Sites of Campania Region recorded 2,507 potentially contaminated sites (ARPAC, 2005). An update in 2009 brought the number to 3,733 (ARPAC, 2009). Furthermore, the assessment of the effects of waste pollution on human health has been controversial and still inconclusive (Cantoni, 2016). In 2004, the Department of Civil Protection commissioned a study focused on cancer incidence and mortality within 196 municipalities in the provinces of Naples and Caserta (WHO Regional Office for Europe et al., 2007) finding positive and statistically significant correlations between health and waste dumping and storage sites. Finally, a review of scientific research on health effects of waste exposure and human biomonitoring in Campania by Triassi et al. (2015: 1230) suggested 'a possible role for waste in the increasing cancer rates detected in the Region'.

To summarize, the organization of urban waste management in Campania relied on the establishment of a patchwork of territorial units hosting processing facilities, storage sites, landfills and the incinerator. The regime of emergency provided both the discursive vehicle and the legal framework through which the government legitimized repression of dissent and the setting up of nodes of management outside ordinary laws. Crucially, this approach to managing waste as profitable business prevented earlier 
implementation of alternative management schemes, and ultimately entangled local socioecologies in metabolic configurations that redefined not just the territorial units where waste was disposed of, but also the entire area between the provinces of Naples and Caserta. In fact, the waste spilled over, physically and symbolically, to a larger political ecological geography, causing widespread yet patchy toxicity.

However, because of the liberalization of the EU waste market in 2008 (Behrsin, 2019), a fraction of Campania's MSW is also shipped north towards other Italian regions and European countries. Turning the excess waste for which Campania lacks treatment capacity into a tradable commodity implies adherence to the protocols laid out by Regulation No 1013/2006 of the European Parliament on shipments of waste and must follow the categorizations of the European Waste Catalogue (EWC), ensuring the non-toxicity of municipal waste exports and their management according to European standards of environmental protection. Then there is the economic aspect: protocols specify the composition, but the price paid to the region or country importing the waste is set through public bids determined in turn by the complex interplay of supply and demand of waste. Currently, the authorized shipments of MSW from Campania comprise the mechanically processed municipal garbage (EWC 19.12.12), the organic fraction from municipal waste (EWC 19.05.01) and dry components of non-hazardous waste, the so-called secondary solid fuel or SSF (EWC 19.12.10). Main destinations of these waste fractions are the incinerators in Hamburg, Germany (Rosenthal, 2008), and Zwentendorf, Austria, where the EVN WTE facility processes $23 \%$ of Italy's exported waste (Niederösterreich Heute, 2013) (see Figure 1) and is paid about $€ 160$ per ton by Campania regional government. These shipments chip away at a popularly-portrayed spatial imaginary of Naples as a filthy, crime-ridden and poorly governed city, and open up opportunities for alternative discursive representations to take hold.

\section{- Zwentendorf, Austria: locking in incineration}

The same waste that disrupted urban order, allowed private profiteering, and triggered protests in Naples has become an important source of municipal revenue and industrial pride in Zwentendorf, a small Austrian municipality of 4,000 residents $1,400 \mathrm{~km}$ north of the southern Italian city (Statistik Austria, 2015). One interviewee recalls the 2013 community meeting in Zwentendorf where an EVN community relations specialist hauled in a wastebasket full of Neapolitan trash. 'See, it's not any different from Austrian waste', she remembers the EVN employee saying as he spilled out the trash on a conference room table (interview, Zwentendorf, 7 July 2015). Community members were told that the garbage they were viewing had been brought from southern Italy, just as EVN was poised to sign the first of a series of year-long contracts to process Neapolitan MSW in Zwentendorf. Naples' first shipment of garbage arrived in Zwentendorf in September 2013 (Foschum, 2013; Zeiler, 2013) to address what the WTE operators claimed was a shortage in access to domestic waste (Seidl-Deubner, 2013; Musulin, 2015). The initial year-long contract stipulated that 90,000 tons of trash would be shipped to the incinerator by rail and processed at the facility. In accordance with EU and Austrian laws that govern the transboundary shipment of waste (interview, Vienna, 10 August 2015), this contract has been extended in year-long increments (EVN community advisory meeting, Zwentendorf, 17 March 2015).

Zwentendorf has a distinctly industrial reputation and identity. This reputation is rooted in a 1916 decision to locate an explosives factory there during world War I, and the subsequent development of a chemical production cluster nearby (Richter et al., 2010). In 1985, Zwentendorf was also chosen as the site of an EVN-Verbund co-owned coal-fired power plant. This power plant was built to supply electricity after a national 1979 anti-nuclear referendum permanently shuttered a nuclear energy facility in Zwentendorf before it went into operation. The waste incinerator opened on the same parcel as the coal-fired plant in 2004. These three facilities-the abandoned nuclear site, the coal-fired facility and the WTE facility-along with the nearby hydroelectric 


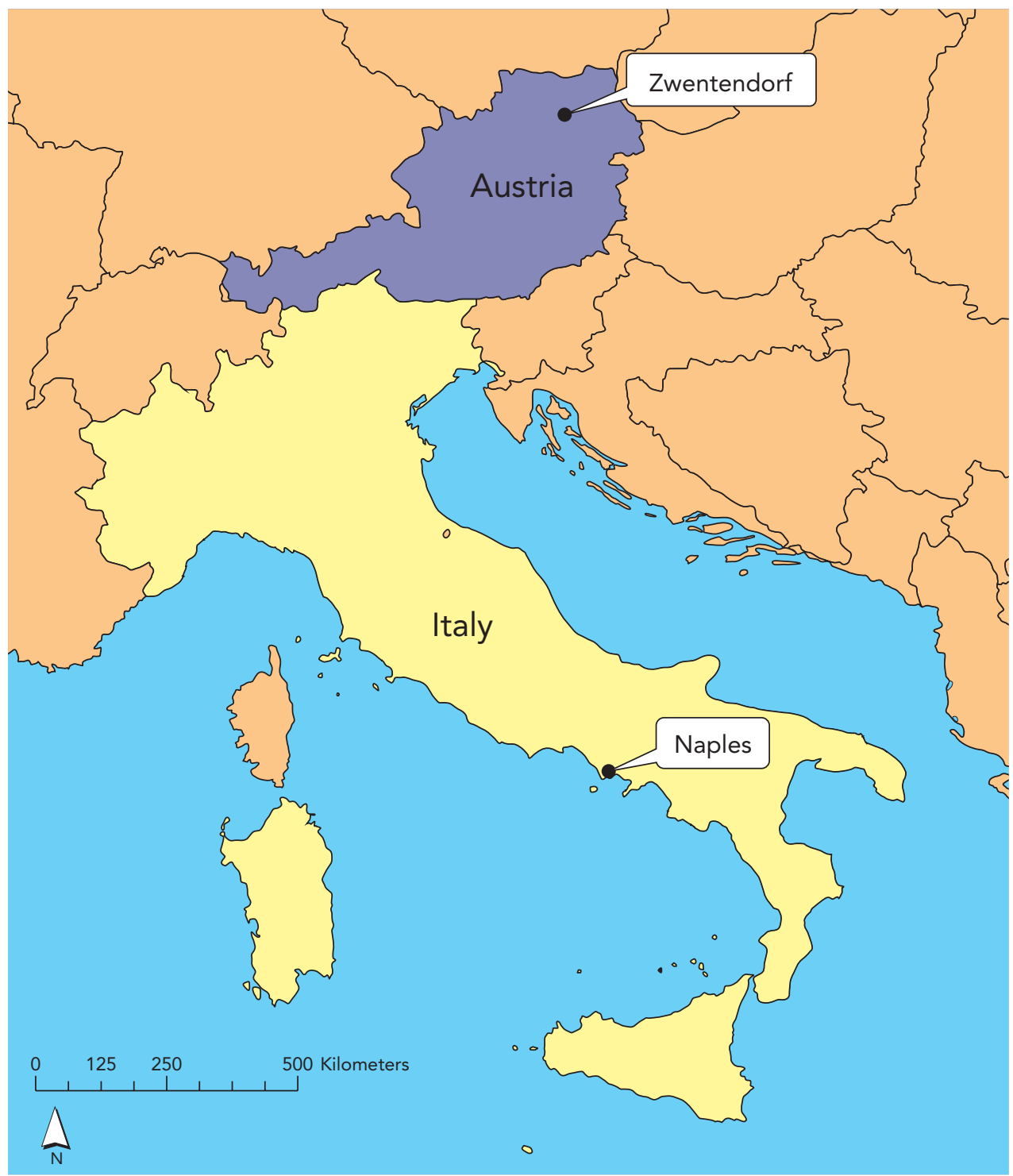

FIGURE 1 Municipal solid waste is shipped from Naples, Italy to Zwentendorf, Austria (map produced by Ingrid Behrsin)

dam make Zwentendorf one of the most significant sites of energy production in Austria (Riegele, 2010). This industrial legacy contributes to residents' perception of Zwentendorf as 'industry-friendly' (interview, Zwentendorf, 18 March 2015), and 'a place where you can do anything' (interview, Zwentendorf, 7 February 2015).

The EVN incinerator shares a turbine with its coal-powered neighbor (Salzer, 2009). This turbine helps deliver either steam or electricity, depending on demand, to local energy clients like tenants in the Donau-Chemie industry complex, as well as throughout the municipality of Zwentendorf. The turbine also drives $140^{\circ} \mathrm{C}$ water to the capital of Lower Austria, St Pölten, located $31 \mathrm{~km}$ southwest of Zwentendorf over a low range of hills. In addition to harnessing energy, incinerating waste generates a significant amount of byproducts. Though incineration allegedly reduces waste to $10 \%$ 
of its initial volume (EVN Abfallverwertung NÖ, nd), matter does not disappear. EVN acknowledges that $32 \%$ of the initial weight is left over in the form of solid residues: slag, boiler ash, scrap iron, fly ash and filter cake (EVN Abfallverwertung NÖ, 2015). The remaining $68 \%$ of the weight mostly exits the facility via the flue-gas stack in the form of $\mathrm{H}_{2} \mathrm{O}$ (steam), but also potential toxins such as carbon monoxide, carbon dioxide, arsenic, sulfur dioxide, nitric oxide, mercury, copper, dioxins and 'dust' (EVN Abfallverwertung NÖ, 2017a; 2017b). Predicting exactly what will come out of the incinerator is an elusive task; it depends to some extent on what the facility takes in.

Zwentendorf's territorial legibility is reinforced by economic arrangements between EVN and the municipality. In recognition of the environmental burdens the incinerator poses for the surrounding region, EVN pays the Zwentendorf municipality a Standordabgabe - a community compensation fee. Specifically, Zwentendorf receives monetary remuneration from EVN based on the tonnage of waste the facility processes each year. In 2010 for example, a year in which Zwentendorf's operating budget was $€ 11.7$ million (Zwentendorf an der Donau, 2016), EVN's community compensation payment amounted to $€ 1$ million (Volkspartei Zwentendorf, 2010) or approximately $8.5 \%$ of the municipal budget. Although neighboring municipalities also sought compensation for increased exposure to the pollution caused by waste shipments and incinerator emissions, Zwentendorf remains the only municipality that receives monetary compensation for the waste incineration (see Figure 2). Municipal leaders in neighboring Atzenbrugg lamented that they were denied a similar arrangement, despite the fact that $90 \%$ of the waste that is processed in the EVN facility is transferred through their rail yard (interview, Atzenbrugg, 21 July 2015). Other municipalities took legal action to obtain compensation for their increased risk of exposure from the waste incinerator, but were likewise denied (Amt der Niederösterreichischen

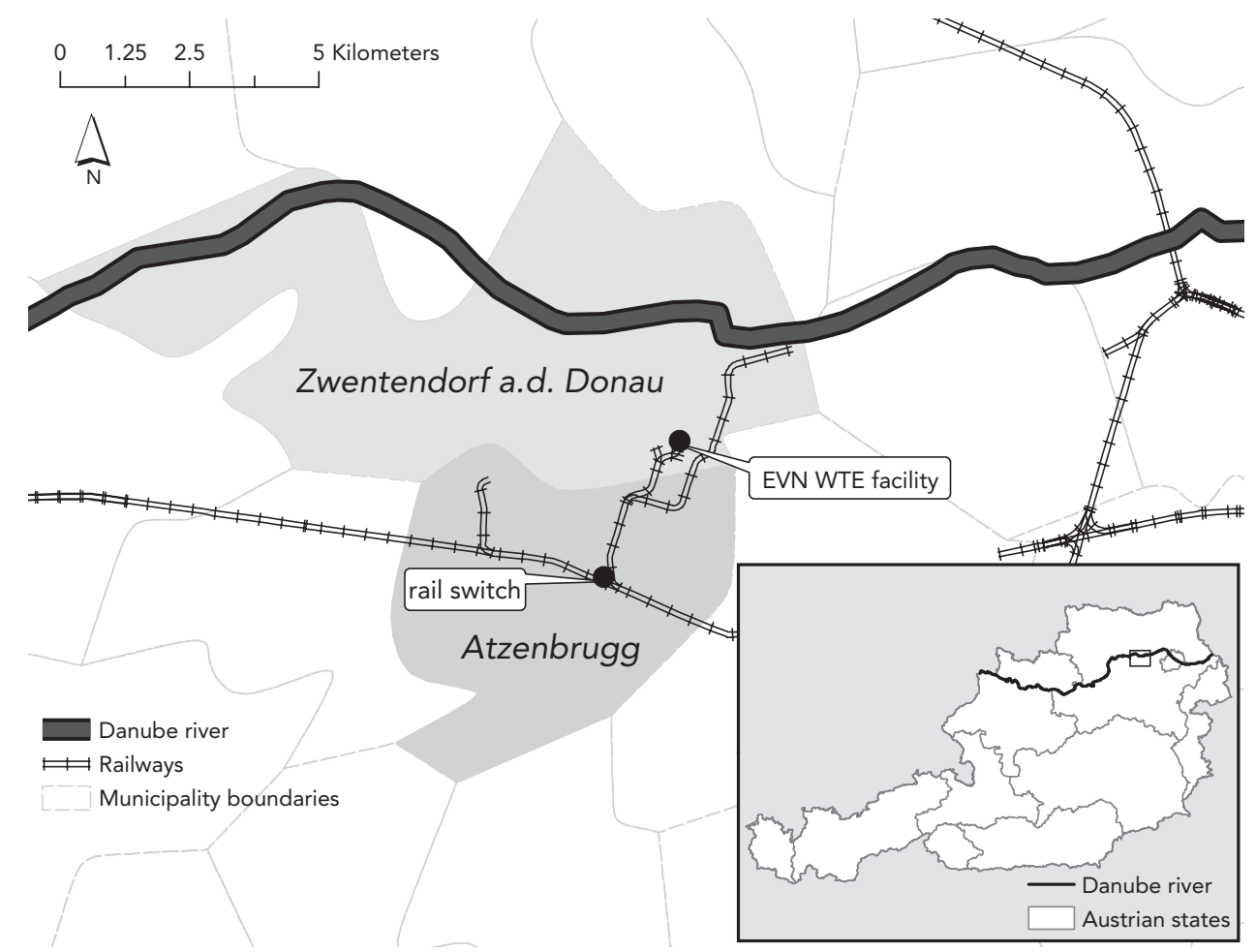

FIGURE 2 Municipalities near the EVN incinerator (map produced by Ingrid Behrsin) 
Landesregierung, 2000). Through the compensation fee, and despite the dispersed nature of the incinerator's emissions and other material remainders, the EVN incinerator serves to reinscribe Zwentendorf's jurisdictional boundary, reinforcing a territorial border that sets Zwentendorf apart from its neighbors.

Zwentendorf's mayor, who has held his position for 20 years, justified the incinerator from the beginning in part by arguing it would attract additional capital investment. As he wrote in the municipally distributed EVN newsletter in 2001, the year the EVN incinerator construction began:

A construction site of this magnitude will surely also bring a large number of companies and professional prospects to the community. For our local producers this is a big opportunity and income possibility! I expect that this unique (WTE) project in Lower Austria will cause ripple effects, so that additional waste management and treatment companies will settle next to the waste incinerator (EVN Abfallverwertung NÖ, 2001: 4).

With the exception of a plastics recycling facility, little additional industry has materialized around the incinerator. Zwentendorf residents remarked in their interviews, however, that the Standordabgabe has helped the municipality invest in additional physical infrastructure like public preschools (which they perceived as rare in Austria), a community center, local transportation systems, swimming pools and subsidized housing. EVN also provides direct sponsorship for municipal amenities such as the local museum (Zwentendorf Mayor's Office, 2009).

Part of what makes the incinerator politically tenable is that much of the matter that is left over from the incineration process does not remain in Zwentendorf. For example, several residents expressed that they felt fine with the industrial emissions in the area because, as one remarked, 'everyone knows that all of our emissions get blown over to Vienna anyway' (interview, Ahrenberg, 7 April 2015). Furthermore, the incinerator's filter cake, where the most toxic byproducts like hormone-disrupting furans and dioxins are concentrated (Connett, 2013), are shipped to hazardous waste disposal sites such as retired salt caverns in Baden-Württemberg, Germany (Austrian Federal Ministry of Agriculture, Forestry, Environment and Water Management and UV\&P Umweltmanagement-Verfahrenstechnik Neubacher \& Partner GmbH, 2010). Likewise, the bottom ash is taken away to landfills elsewhere. The metabolism of these particular material components from the MSW thus contributes to the fetishization of MSW in Zwentendorf as an energy source, and Zwentendorf as an energy community. Building on observations by Levidow and Raman (2019: 108), we find that policies that allow for the transboundary shipment of waste '[shift] the ontological status of waste from matter out of place to a resource'. However, the circulation and incineration of southern Italian waste, among other sources, also masks more sustainable alternatives, including those lifted up by the European Commission's own 2008 Waste Framework Directive, which established a waste hierarchy that elevates waste reduction and recycling above incineration. Despite this hierarchy, incineration has in fact outpaced recycling since the passage of the Waste Framework Directive, with the European Investment Bank investing $62 \%$ of its waste management budget in incineration projects (Behrsin, 2019).

St Pölten, Austria: constructing a capital for lower Austria

Waste metabolism also plays a central role in constructing territorialized imaginaries of modern cities in the case of both Naples and St Pölten. But while removing waste from Naples' central streets helped construct an imaginary of a modern, sanitized city, using the southern Italian waste's latent energy serves to build up St Pölten's image as Lower Austria's modern, up-and-coming new capital. While MSW is always heterogeneous, it consistently contains carbon, both fossil (in the form of 
plastic) and biogenic (e.g. food waste). Furthermore, within the EU, MSW is treated as a partially biogenic fuel source, given the working assumption that $60 \%-70 \%$ of its mass is composed of organic material (Austrian Federal Ministry of Agriculture, Forestry, Environment and Water Management and UV\&P UmweltmanagementVerfahrenstechnik Neubacher \& Partner GmbH, 2010). Constructed in 2009, the pipeline that transports hot water from Zwentendorf's power plants to St Pölten's district heating system is $31 \mathrm{~km}$ long-the longest of its kind in Austria (Oberhammer, 2010). Despite the distance it travels, the water loses only $2^{\circ} \mathrm{C}$ on its journey (Fernwärme St Pölten, 2016). Within St Pölten (population 50,000), the hot water heats apartment buildings, single-family homes, businesses, government buildings and the state hospital before returning to Zwentendorf to be reheated.

For St Pölten's political elites, the pipeline bolstered the city's pursuit for recognition as an entrepreneurial, green state capital. For example, the coupling of the Zwentendorf-St Pölten pipeline with a new district cooling system for the regional hospital led St Pölten's mayor to proclaim that the project 'brings together all the advantages of a modern project: sustainable, environment- and climate-friendly, economical! With it, St. Pölten proves once again its pioneering role in energy and environmental policy' (Bürgermeister Zeitung, nd). In addition to touting the ways in which the pipeline had contributed to modernizing the city, municipal and EVN representatives also praised the project for helping the city gain independence from international energy markets, as well as an 'image boost', particularly from the 2009 Climate Star award the project received from the Climate Alliance-an international network of 1,700 European municipalities dedicated to climate action (Klimabündnis Österreich, 2015). Lower Austria's governor similarly proclaimed the pipeline a 'showcase project' (Salzer, 2009).

For many UPE scholars, especially those who examine the role of infrastructural investment in urban modernization efforts (cf. Kaika and Swyngedouw, 2000; Gandy, 2004; Kaika, 2005; 2006; Monstadt, 2009), the notion that pipelines and other infrastructural networks contribute to the production of territorialized urban spaces is not a new one. Yet in St Pölten these investments in energy infrastructure take on additional significance as they underscore St Pölten's endeavor to establish an imaginary of the city as Lower Austria's regional capital, out of the shadow of the nearby national capital: Vienna. On a political map, the city-state of Vienna appears as an island within the much larger state of Lower Austria (see Figure 3). Vienna and Lower Austria became two separate federal states shortly after world war I (1922), but the Palais Niederösterreich-a villa in Vienna's inner city-remained the Lower Austrian state headquarters until 1997, when the Lower Austrian government offices officially moved to St Pölten, $60 \mathrm{~km}$ west of Vienna. This move was Siegfried Ludwig's, the governor of Lower Austria from 1981 to 1992, signature achievement. Marshaled under the slogan 'A state without a capital is like goulash without juice!' (Riepl, 1987), Ludwig's campaign ended successfully with a 1986 Lower Austrian parliamentary resolution to move the government outside of Vienna. Constructing or moving a state capital is recognized as a governance technology that serves to territorialize political jurisdiction (Koch, 2013), an insight that is reflected in St Pölten's development as a new capital for Lower Austria.

For the city's and region's economic and political leaders, turning St Pölten into Lower Austria's capital offered opportunities for the city to grow in terms of capital investment in buildings and infrastructure. The chief of staff for future development, business, and marketing in the city office of the magistrate stated, for example:

To become a regional capital is one thing. To utilize that opportunity is another. We've utilized it. It's also important to note that it's not only businesses that have invested in this location, but also individuals ... Since 2001500 families have built homes here; that represents an investment of approximately $€ 150$ million (Platform, 2020: 2012). 




FIGURE 3 Vienna and Lower Austria (map produced by Ingrid Behrsin)

The pipeline that originates outside the Zwentendorf WTE facility and carries hot water destined for St Pölten's district heating system has propelled this development. As a municipal representative for St Pölten's district heating system company explained, one of the main benefits of the pipeline for the municipality is that residential development projects become eligible for subsidies from the Lower Austrian government when they are connected to 'biogenic' energy sources like the EVN WTE facility. 'It's therefore more lucrative for developers of residential buildings to connect to the district heating system, because there are appealing subsidies for that' (interview, St Pölten, 26 January 2015). Thus, in St Pölten, waste generated in southern Italy and incinerated in Zwentendorf helps perform both the political and physical territorialization of Lower Austria's emergent capital.

Yet for all the pride St Pölten's leadership has taken in its 'green' energy procurement and urban development, enthusiasm surrounding the infrastructural development obscures the fact that waste is a relatively inefficient fuel source. Indeed, the Austrian Ministry for Agriculture, Forestry, Environment and Water Management claims that an average kilo of MSW contains the energy equivalent of $1 \mathrm{~kg}$ of brown coal (Austrian Federal Ministry of Agriculture, Forestry, Environment and Water Management and UV\&P Umweltmanagement-Verfahrenstechnik Neubacher \& Partner $\mathrm{GmbH}, 2010)$. Incinerators have also been some of the primary targets of decades of environmental justice campaigns that organize against the dioxins, furans and carbon dioxide they are known to emit (Pellow, 2004). By tethering its district heating and cooling system to this primarily fossil fuel-based, yet certified 'green', energy source, St Pölten has locked itself into a new form of energy dependence, namely, on MSW. 


\section{Conclusion}

In this article, we argued that metabolic circulation and territorialization-of waste economies, in this case-co-constitute urbanization processes in ways that, first, hide socioecological costs in one place to facilitate valorization in another; and second, by producing specific spatial configurations, hamper opportunities for alternative, more sustainable metabolisms. We attempted to expand UPE's explanatory reach by combining the analytic of socioecological metabolism with approaches to territorialization developed by recent political geography scholarship. We staged an empirical application of this conceptual encounter by attending to a multi-sited case study in which the metabolism of MSW provided the entry point to expose how interconnected yet qualitatively different urbanization processes rely on both circulation and territorialization to foster, facilitate and realize various forms of accumulation. Attending to the production of territories of waste management reveals the ways in which specific portions of urban and rural space are subsumed within the metabolic circulatory process inherent to waste management and capital accumulation. It highlights the role played by relations of power condensed in the infrastructural nodes that allow the monetary valorization of socionatures-in this case, waste and land.

The interlinked metabolic and territorialization processes described in the sections above underscore how 'materiality and political economy are dialectically related and co-constitute urban metabolisms' (Demaria and Schindler, 2016: 297). Crucially, waste's material polyvalence is both leveraged by and contributes to producing local urbanization and territorialization dynamics in each site. By bringing critical waste scholarship into conversation with urbanization and territorialization literature, we have aimed to show how selective discursive renderings of waste's material characteristics influence the ways in which 'transnational urbanisms operate in rather sticky, history-laden contexts that shape what goes where and how, as well as in what form they materialize' (Jacobs, 2012: 414). In Naples, waste is being moved beyond the central city to toxified peripheries and to international sites like Zwentendorf, constructing interlinked imaginaries of a sanitized inner city and discordant periphery, and paving the way for the construction of capital-intensive infrastructure projects. By paying foreign countries to take their waste in excess, Campania's regional government engenders a peculiar trade in which the MSW's polyvalence-at the same time a potential contaminant and a potential fuel-renders it a negative commodity for which it pays for disposal. In contrast, in Zwentendorf, the same waste is rendered as an energy source that generates income for the small municipality, reinforcing the town's industrial reputation and creating opportunities for additional civic amenities. Lastly, the steam generated in Zwentendorf's WTE facility and pumped to St Pölten has helped political leaders market the capital as a clean and modern alternative to Vienna, and also bolster the local real estate market. Each of these local tendencies is made possible by the relationships these sites-Naples, Zwentendorf and St Pölten-have with one another, facilitated by the circulation of waste and its latent energy. In tracing the movement of waste and energy, and their discursive renderings, among these sites, this article has responded to calls for UPE studies to attend to the 'dialectical shaping of wider landscapes through processes of urbanization' (Silver, 2015: 999).

In each location, these particular, but interlinked, metabolisms and territorializations have stymied more socioecologically sustainable alternatives and, sometimes, democratic initiatives. In southern Italy grassroots anti-dumping activists campaigned for waste reduction, reuse, sorting and recycling; each of these approaches is higher on the EU's 2008 Waste Framework Directive's waste hierarchy. In Zwentendorf, the construction of one of the largest incinerators in Europe drives a political economy of waste management that depends on the constant delivery of excess MSW, including from across national borders. Crucially, this relies on the liberalization of the EU waste market that emerged through the 2008 
EU Waste Framework Directive, and is in fact in direct contradiction to Directive's explicit prioritization, as stated above, of waste reduction, reusing and recycling over incineration. In St Pölten, a district heating/cooling line is now connected to the wastefueled steam generated by the Zwentendorf incinerator rather than imported natural gas. Yet, as Austrian scientific agencies themselves have pointed out, waste itself is a low-efficiency fuel, raising important questions as to the ecological sustainability of this energy network.

Indeed, what emerges in this study, and points to avenues for future research, is that waste's polyvalence-its ability to repel, catalyze, burn and power-opens up markedly different political possibilities depending on the political-economic and geographical contexts it encounters. In Naples, Zwentendorf and St Pölten, MSW takes on contrasting characteristics and enacts different relationships, depending on the infrastructure, economic arrangements, policies, histories and climatological conditions prevalent in each location. The contrasting examples of the roles that waste plays in the socio-environmental fabric of these three locations highlight the fact that waste itself is not deterministic; there are opportunities for its function and materiality to be contested and expressed differently. Future research on the urban metabolism of waste should therefore more deeply examine the power relations that condition which actors' claims about waste's material properties and uses are acted upon, and how these claims are contested and reworked. UPE studies might ask, for example, 'Who is able to make claims about the materiality of waste (and other resources), and thus control storylines about urbanization?'.

Ingrid Behrsin, Office of Public Scholarship and Engagement, 181 Hunt Hall, University of California, Davis, One Shields Ave., Davis, CA 95616, USA, iabehrsin@ ucdavis.edu

Salvatore Paolo De Rosa, Environmental Humanities Laboratory, Division of History of Science, Technology and Environment, KTH Royal Institute of Technology, Teknikringen 74D, level 5, Stockholm, Sweden, salvatore.paolo.derosa@abe.kth.se

\section{References}

Amt der Niederösterreichischen Landesregierung (2000) Bescheid RU4-U-035/084 [Report RU4035/084] [WWW document]. URL http://www5 umweltbundesamt.at/uvpdb/docs/Bescheide/ MVAZwentendorf/Bescheid.pdf (accessed 6 December 2019).

Arboleda, M. (2016) In the nature of the non-city: expanded infrastructural networks and the political ecology of planetary urbanisation. Antipode 48.2, 233-51.

Armiero, M. and G. D'Alisa (2012) Rights of resistance: the garbage struggles for environmental justice in Campania, Italy. Capitalism Nature Socialism 23.4, 52-68.

Armiero, M. and G. D'Alisa (2013) Voices, clues, numbers: roaming among waste in Campania. Capitalism Nature Socialism 24.4, 7-16.

Armiero, M. and S.P. De Rosa (2018) Political effluvia: smells, revelations, and the politicization of daily experience in Naples, Italy. In J. Thorpe, S. Rutherford and L.A. Sandberg (eds.), Methodological challenges in natureculture and environmental history research, Routledge, Abingdon, Oxon and New York, NY.

ARPAC (2005) Piano Regionale Di Bonifica Dei Siti Inquinati Della Regione Campania [Regional plan for remediation of polluted sites of the Campania region]. ARPAC, Naples.

ARPAC (2009) Relazione Sullo Stato Dell'ambiente in Campania 2009 [Report on the state of the environment in Campania 2009]. ARPAC, Naples.

Austrian Federal Ministry of Agriculture, Forestry, Environment and Water Management, UV\&P Umweltmanagement-Verfahrenstechnik Neubacher
\& Partner GmbH (2010) Waste-to-energy in Austria: white book-figures, data, facts. Second edition [WWW document]. URL http://www.uvp.at/?html=4.1 publications_whitebook\&ch=1 (accessed 6 December 2019).

Behrsin, I. (2019) Rendering renewable: technoscience and the political economy of waste-to-energy regulation in the European Union. Annals of the American Association of Geographers 109.5, 1362-78.

Bluwstein, J. and J.F. Lund (2018) Territoriality by conservation in the Selous-Niassa corridor in Tanzania. World Development 101 (January), 453-65.

Brenner, N. and S. Elden (2009) Henri Lefebvre on state, space, territory. International Political Sociology 3.4, 353-77.

Brownell, E. (2011) Negotiating the new economic order of waste. Environmental History 16.2, 262-89.

Bryan, J. (2012) Rethinking territory: social justice and neoliberalism in Latin America's territorial turn. Geography Compass 6.4, 215-26.

Bürgermeister Zeitung (nd) Zukunftsorientierte Technologie für St Pölten-Fernkälteversorgung für das Landesklinikum [Future-oriented technology for St Pölten-district cooling for the state hospital] [WWW document]. URL http://www.buergermeisterzeitung info/aus_den_gemeinden/mehr.html.php?nr $=44364$ (accessed 4 December 2014).

Cantoni, R. (2016) The waste crisis in Campania, South Italy: a historical perspective on an epidemiological controversy. Endeavour 40.2, 102-13.

Castán Broto, V. and H. Bulkeley (2013) Maintaining climate change experiments: urban political ecology and 
the everyday reconfiguration of urban infrastructure. International Journal of Urban and Regional Research 37.6, 1934-48.

Christophers, B. (2014) The territorial fix: price, power and profit in the geographies of markets. Progress in Human Geography 38.6, 754-70.

Clapp, J. (2002) What the pollution havens debate overlooks. Global Environmental Politics 2.2, 11-19.

Connett, P. (2013) The zero waste solution: untrashing the planet one community at a time. Chelsea Green Publishing, White River Junction, VT.

Corson, C. (2011) Territorialization, enclosure and neoliberalism: non-state influence in struggles over Madagascar's forests. The Journal of Peasant Studies 38.4, 703-26.

Crampton, J.W. (2010) Cartographic calculations of territory Progress in Human Geography [WWW document]. URL http://phg.sagepub.com/content/early/2010/01/28/0 309132509358474 (accessed 25 October 2016).

Crang, M., A. Hughes, N. Gregson, L. Norris and F. Ahamed (2013) Rethinking governance and value in commodity chains through global recycling networks. Transactions of the Institute of British Geographers 38.1, 12-24.

D'Alisa, G., D. Burgalassi, H. Healy and M. Walter (2010) Conflict in Campania: waste emergency or crisis of democracy. Ecological Economics 70.2, 239-49.

D'Alisa, G., A.R. Germani, P.M. Falcone and P. Morone (2017) Political ecology of health in the Land of Fires: a hotspot of environmental crimes in the south of Italy. Journal of Political Ecology 24.1, 59-86.

De Rosa, S.P. (2018) A political geography of 'waste wars' in Campania (Italy): competing territorialisations and socio-environmental conflicts. Political Geography 67 (November), 46-55.

Demaria, F. and S. Schindler (2016) Contesting urban metabolism: struggles over waste-to-energy in Delhi, India. Antipode 48.2, 293-313.

Dines, N. (2013) Bad news from an aberrant city: a critical analysis of the British press's portrayal of organised crime and the refuse crisis in Naples. Modern Italy 18.4, 409-22.

Donadio, R. (2010) Berlusconi faces public discontent over Italy's trash crisis. The New York Times 28 October [WWW document]. URL http://www.nytimes. com/2010/10/29/world/europe/29italy.html (accessed 15 August 2015).

Elden, S. (2010) Land, terrain, territory. Progress in Human Geography 34.6, 799-817.

Emerson, R.M., R.I. Fretz and L.L. Shaw (2011) Writing ethnographic fieldnotes. Second edition, University of Chicago Press, Chicago, IL.

EVN (2002) Größte Österreichische Müllverbrennungsanlage Erhält Europäische Projektfinanzierung [Biggest Austrian waste incinerator receives European project financing] [WWW document]. URL https://www.evn.at/EVN-Group/ Medien/Importiere-Meldungen/Gro\%C3\%9Fteosterreichische-Mullverbrennungsanlage-erha.aspx (accessed 15 August 2015).

EVN Abfallverwertung NÖ (2001) Bürger-Info [Citizen information]. No. 1/2001 [WWW document]. URL http://www.evn-abfallverwertung.at/de/buerger/ avnzeitung-archiv.asp (accessed 16 August 2015).

EVN Abfallverwertung NÖ (2015) Residuals [WWW document]. URL http://www.evn-abfallverwertung.at/ en/umwelt/reststoffe.asp (accessed 15 August 2015).

EVN Abfallverwertung NÖ (2017a) Emissionen [Emissions] [WWW document]. URL http://www.evnabfallverwertung.at/Abfall/Umwelt/Emissionen.aspx (accessed 12 January 2017).

EVN Abfallverwertung NÖ (2017b) Emissionsdaten Linie 1 [Emissions Line 1] [WWW document]. URL http://www. evn-abfallverwertung.at/Abfall/Umwelt/Emissionen. aspx (accessed 12 January 2017).

EVN Abfallverwertung NÖ (nd) Technik Und Kompetenz die Thermische Abfallverwertungsanlage Zwentendorf/ Dürnrohr [Technique and competence: the Zwentendorf/Dürnrohr thermal waste incinerator]. [WWW document]. URL http://www.evn- abfallverwertung.at/de/aktuell/index.asp (accessed 15 August 2015)

Fernwärme St Pölten (2016) Da Kommt die Wärme Her [That is where the heat comes from] [WWW document]. URL http://www.fernwaerme-stp.at/fernwaerme/da-kommtdie-waerme-her/ (accessed 2 November 2016).

Foschum, M. (2013) Das Geschäft mit dem Italo-Müll [The business with the Italian trash]. Kurier 31 August [WWW document]. URL http://kurier.at/chronik/ niederoesterreich/zwentendorf-das-geschaeft-mitdem-italo-muell/24.815.640 (accessed 7 September 2013).

Gandy, M. (2004) Rethinking urban metabolism: water, space and the modern city. City 8.3, 363-79.

Gandy, M. (2005) Cyborg urbanization: complexity and monstrosity in the contemporary city. International Journal of Urban and Regional Research 29.1, 26-49.

Gille, Z. (2007) From the cult of waste to the trash heap of history: the politics of waste in socialist and postsocialist Hungary. Indiana University Press, Bloomington, IN.

Gille, Z. (2013) Is there an emancipatory ontology of matter? A response to Myra Hird. Social Epistemology Review and Reply Collective 2.4, 1-6.

Grant, R. and M. Oteng-Ababio (2012) Mapping the invisible and real 'African' economy: urban e-waste circuitry. Urban Geography 33.1, 1-21.

Halvorsen, S. (2018) Decolonising territory: dialogues with Latin American knowledges and grassroots strategies. Progress in Human Geography [WWW document]. URL https://doi.org/10.1177/0309132518777623 (accessed 6 December 2019).

Harvey, D. (1996) Cities or urbanization? City 1.1/2, 38-61.

Harvey, P. (2017) Waste futures: infrastructures and political experimentation in southern Peru. Ethnos 82.4, 672-89.

Heynen, N. (2014) Urban political ecology. I: The urban century. Progress in Human Geography 38.4, 598-604.

Heynen, N., M. Kaika and E. Swyngedouw (2006) In the nature of cities: urban political ecology and the politics of urban metabolism. New edition, Routledge, London.

Hird, M.J. (2012) Knowing waste: towards an inhuman epistemology. Social Epistemology 26.3/4, 453-69.

INEA (2014) Agricoltura nella Terra dei Fuochi [Agriculture in the land of fires]. Istituto Nazionale di Economia Agraria, Rome.

Jacobs, J.M. (2012) Urban geographies. I: Still thinking cities relationally. Progress in Human Geography 36.3, 412-22.

Kaika, M. (2005) City of flows: modernity, nature, and the city. Routledge, New York.

Kaika, M. (2006) Dams as symbols of modernization: the urbanization of nature between geographica imagination and materiality. Annals of the Association of American Geographers 96.2, 276-301.

Kaika, M. and E. Swyngedouw (2000) Fetishizing the modern city: the phantasmagoria of urban technological networks. International Journal of Urban and Regional Research 24.1, 120-38.

Kaye, L. (2011) Community groups tackle Naples' rubbish problem. The Guardian 18 August [WWW document]. URL http://www.theguardian.com/sustainablebusiness/naples-waste-management-problemcommunity-groups (accessed 15 August 2015).

Keil, R. (2003) Urban political ecology. Urban Geography 24.8, 723-38.

Kington, T. (2007) Naples burns as residents protest at garbage crisis. The Guardian 27 May [WWW document]. URL http://www.theguardian.com/environment/2007/ may/27/italy.waste (accessed 15 August 2015).

Klimabündnis Österreich (2015) Fernwärme Dürnrohr-St Pölten [District heating Dürnrohr-St Pölten] [WWW document]. URL http://www.klimabuendnis.at/ fernwaerme-duernrohr-stpoelten (accessed 15 August 2015).

Koch, N. (2013) The 'heart' of Eurasia? Kazakhstan's centrally located capital city. Central Asian Survey 32.2, 134-47.

Kowalcze, K. (2015) Das Geschäft mit Abfall erhöht den Gewinn der EVN Abfallwirtschaft [The business with 
waste raises profits for the EVN waste economy]. WirtschaftsBlatt 27 February, 5.

Levidow, L. and S. Raman (2019) Metamorphosing waste as a resource: scaling waste management by ecomodernist means. Geoforum 98 (January), 108-22.

Monstadt, J. (2009) Conceptualizing the political ecology of urban infrastructures: insights from technology and urban studies. Environment and Planning A: Economy and Space 41.8, 1924-42.

Moody's Investors Service (2008) Moody's downgrades the Italian city of Naples' debt to A2: stable outlook [WWW document]. URL https://www.moodys.com/research/ Moodys-downgrades-the-Italian-City-of-Naples-debtto-A2--PR_150653 (accessed 3 November 2015).

Moore, S.A. (2008) The politics of garbage in Oaxaca, Mexico. Society \& Natural Resources 21.7, 597-610.

Moore, S.A. (2009) The excess of modernity: garbage politics in Oaxaca, Mexico. The Professional Geographer 61.4, 426-37.

Murphy, A.B. (2012) Entente territorial: Sack and Raffestin on territoriality. Environment and Planning D: Society and Space 30.1, 159-72.

Musulin, K. (2015) Germany faces an awkward trash problem: there's not enough of it. Waste Dive [WWW document]. URL http://www.wastedive.com/news/ germany-faces-an-awkward-trash-problem-theres-notenough-of-it/407730/ (accessed 9 November 2015).

Nadeau, B. (2010) Naples suffers as garbage piles up. Newsweek 27 October [WWW document]. URL http://www.newsweek.com/naples-suffers-garbagepiles-73753 (accessed 15 August 2015)

Newell, J.P. and J.J. Cousins (2014) The boundaries of urban metabolism: towards a political-industrial ecology. Progress in Human Geography [WWW document]. URL https://doi.org/10.1177/0309132514558442 (accessed 6 December 2019).

Niederösterreich Heute (2013) 90.000 Tonnen: Zwentendorf verbrennt jetzt Müll aus Neapel [90,000 tonnes: Zwentendorf now burns waste from Naples]. Niederösterreich Heute 30 August [WWW document]. URL http://www.heute.at/news/oesterreich/noe/ art23654,921196 (accessed 7 September 2013).

Nixon, R. (2011) Slow violence and the environmentalism of the poor. Harvard University Press, Cambridge, MA

Oberhammer, A. (2010) Die Längste Fernwärmeleitung Österreichs [Austria's longest district heating pipeline] [WWW document]. URL https://www.gaswaerme.at/ de/pdf/10-1/oberhammer.pdf (accessed 12 December 2014)

O'Brien, M. (1999) Rubbish values: reflections on the political economy of waste. Science as Culture 8.3, 269-95.

O'Brien, M. (2007) A crisis of waste? Understanding the rubbish society. First edition, Routledge, New York, NY.

Painter, J. (2010) Rethinking territory. Antipode 42.5, 1090-118.

Parliamentary Commission on Waste (2018) Relazione territoriale sulla regione Campania [Territorial report on Campania region]. Doc. XXIII N.52, Camera dei deputati e Senato della Repubblica [Chamber of Deputies and Senate of the Republic], approved 28 February (available at http://leg17.senato.it/service/ PDF/PDFServer/BGT/1066718.pdf).

Pasotti, E. (2010) Sorting through the trash: the waste management crisis in southern Italy. South European Society and Politics 15.2, 289-307.

Pellow, D.N. (2004) Garbage wars: the struggle for environmental justice in Chicago. MIT, Cambridge, MA

Platform 2020 (2012) Fortschrittsbericht zum Unternehmen Zukunft [Progress report on the project future]. St. Pölten 2020. St. Pölten, Marketing St. Pölten GmbH.

Pomeroy, R. (2008) Naples streets now free of trash but also tourists. Reuters UK, 25 March [WWW document]. URL http://uk.reuters.com/article/2008/03/25/lifestyleitaly-naples-dc-idUKL254793520080325 (accessed 29 October 2015)

Rabitti, P. (2008) Ecoballe [Eco-bales]. Aliberti, Rome.

Rasmussen, M.B. and C. Lund (2018) Reconfiguring frontier spaces: the territorialization of resource control. World Development 101 (January), 388-99.
Reno, J. (2015) Waste and waste management. Annual Review of Anthropology 44.1, 557-72.

Rice, J.L. (2010) Climate, carbon, and territory: greenhouse gas mitigation in Seattle, Washington. Annals of the Association of American Geographers 100.4, 929-37.

Richter, R., F. Rieder and J. Stradl (2010) Industriegeschichte [Industrial history]. In Marktgemeinde Zwentendorf an Der Donau: Heimatbuch [Municipality Zwentendorf an der Donau: Homeland book], Rötzer-Druck GesmbH, Eisenstadt, Burgenland.

Ridet, P. (2010) Naples remains in the grip of a waste nightmare. The Guardian 19 October [WWW document]. URL http://www.theguardian.com/ world/2010/oct/19/naples-chaos-waste-mountain (accessed 15 August 2015).

Riegele, G. (2010) Die EVN in Zwentendorf [EVN in Zwentendorf]. In Marktgemeinde Zwentendorf an Der Donau: Heimatbuch [Municipality Zwentendorf an der Donau: Homeland book], Rötzer-Druck GesmbH Eisenstadt, Burgenland.

Riepl, H. (1987) Die niederösterreichische Landeshauptstadt: Vision und Wirklichkeit : Dokumentation [Lower Austria's state capital: vision and reality: documentation]. Niederösterreichisches Pressehaus Druck- und Verlagsgesellschaft, St Pölten

Rosenthal, E. (2008) A whiff of Naples arrives in Hamburg. The New York Times 9 June [WWW document]. URL http:// www.nytimes.com/2008/06/09/world/europe/09trash. html?pagewanted=all (accessed 27 October 2013).

Roth, R.J. (2008) 'Fixing' the forest: the spatiality of conservation conflict in Thailand. Annals of the Association of American Geographers 98.2, 373-91.

Sack, R.D. (1986) Human territoriality: its theory and history [Cambridge studies in historical geography]. Cambridge University Press, Cambridge.

Salzer, K. (2009) Lange Leitung und stolz darauf [Long pipeline and proud of it]. Kurier 2 October, 20.

Seidl-Deubner, K. (2013) Italienischer Müll für St. Pölten-Neapels Müll wird heuer St Pöltner Haushalte heizen. Zwentendorf entsorgt italienische Abfälle [Italian waste for St Pölten-Naples' waste will now heat St Pölten's households. Zwentendorf disposes of Italian wastes]. Bezirks Bläter Absdorf 4 Sepember [WWW document]. URLhttp://www. meinbezirk.at/absdorf/chronik/italienischer-muell-fuerstpoelten-d675463.html (accessed 7 September 2013).

Silver, J. (2015) Disrupted infrastructures: an urban political ecology of interrupted electricity in Accra. International Journal of Urban and Regional Research 39.5, 984-1003.

Statistik Austria (2015) Bevölkerung nach Gemeinden am 1.1.2015 [Population by municipality on 1.1.2015] [WWW document]. URL http://www.statistik.at/wcm/ idc/idcplg? IdcService=GET_PDF_FILE\&RevisionSele ctionMethod $=$ LatestReleased \&dDocName $=064320$ (accessed 6 December 2019).

Swyngedouw, E. (1996) The city as a hybrid: on nature, society and cyborg urbanization. Capitalism Nature Socialism 7.2, 65-80.

Swyngedouw, E. and N. Heynen (2003) Urban political ecology, justice and the politics of scale. Antipode 35.5, 898-918

Triassi, M., R. Alfano, M. Illario, A. Nardone, O. Caporale and P. Montuori (2015) Environmental pollution from illegal waste disposal and health effects: a review on the 'triangle of death'. International Journal of Environmental Research and Public Health 12.2, 1216-36.

Vandergeest, P. and N.L. Peluso (1995) Territorialization and state power in Thailand. Theory and Society 24.3, 385-426.

Volkspartei Zwentendorf (2010) Zwentendorfer Reporter: Informationsblatt der Volkspartei Zwentendorf [Zwentendorfer Reporter: information pamphlet of Zwentendorf's People's Party], 2/2010 [WWW document]. URL http://www.oevp-zwentendorf.at/ reporter/Rep1003.pdf (accessed 16 August 2015).

WHO Regional Office for Europe et al. (2007) Trattamento Dei Rifiuti in Campania. Correlazione tra rischio ambientale da rifiuti, mortalitá e malformazioni congenite [Treatment of waste in Campania. Correlation between environmental risk from waste, mortality, and congenital malformations]. Rapporto 
sintetico [WWW document]. URL http://www. protezionecivile.gov.it/resources/cms/documents/ sintesi_dello_studio.pdf (accessed 6 June 2018).

Zeiler, K. (2013) Das Geschäft mit dem Italo-müll aus Neapel [The business with the Italian waste from Naples]. meinbezirk.at 16 September [WWW document]. URL http://www.meinbezirk.at/tulln-an-der-donau/ politik/das-geschaeft-mit-dem-italo-muell-ausneapel-d690481.html (accessed 5 March 2015).
Zwentendorf an Der Donau (2016) Offener Haushalt [Open household] [WWW document]. URL https://www.

offenerhaushalt.at/gemeinde/zwentendorf-der-donau/ finanzdaten/hauptansicht/top/absolut/2010/ausgaben (accessed 26 April 2016).

Zwentendorf Mayor's Office (2009) Rathauspost [City Hall News], 5/2009 [WWW document]. URL http://www.zwentendorf. at/system/web/zeitung.aspx?menuonr=218422632 (accessed 6 December 2019). 